\title{
KEWENANGAN DAN TANGGUNG JAWAB NOTARIS DALAM PEMBUATAN AKTA PERJANJIAN KAWIN PASCA PUTUSAN MAHKAMAH KONSTITUSI NO 69/PUU-XII/2015
}

\author{
Wahyuni, Rachmat Safa'at, Muhammad Fadli \\ Program Studi Magister KenotariatanFakultas Hukum Universitas Brawijaya \\ Jl.MT.Haryono Nomor 169, Malang \\ email:yuni.cahyanto@yahoo.com
}

\begin{abstract}
This Study discusses the legislation ratios of Constitutional Court Decision Number 69/ PUU-XIII/2015 and its legal implications on the authority of a notary in the establishment of a marriage certificate after the Constitutional Court Decision Number 69/PUU-XIII/2015 concerning the marriage agreement that can be made after the marriage (a study of a notary in East Jakarta).The results of this study are what is the basis of the legislation ratio of the Constitutional Court (MK) issued Decision of the Constitutional Court (MK) Number 69/PUU-XIII/2015 on the making of marriage agreements that can be made not only before the marriage but can also be made after the marriage throughout the period of marriage and its legal implications to the authority of notary in the making of the deed of marriage agreement after the Decision of the Constitutional Court Number 69/ PUU-XIII/2015, because the Constitutional Court's decision is final and binding, a notary must respect and execute Decision of the Constitutional Court Number 69/PUU-XIII/2015 concerning the marriage agreement made by the parties may be made after the marriage and must be valid by the competent marriage official or notary public
\end{abstract}

Keywords: marriage agreement, notary authority, court decision No.69 / PUU-XIII / 2015

\begin{abstract}
Abstrak: Kajian ini membahas mengenai rasio legisPutusan MahkamahKonstitusi Nomor69/PUUXIII/2015 dan implikasi hukumnya terhadap kewenangan notaris dalam pembuatan aktaperjanjian kawin pasca Putusan Mahkamah Konstitusi Nomor 69/PUU-XIII/2015 tentang perjanjian kawin yang bisa dibuat setelah terjadinya perkawinan (studi pada notaris di wilayah Jakarta Timur). Hasil penulisan artikel ilmiah ini adalah apa yang menjadi dasar rasio legis Mahkamah Konstitusi (MK) mengeluarkan Putusan Mahkamah Konstitusi (MK) Nomor 69/PUU-XIII/2015 tentang pembuatan perjanjian kawin yang bisa dibuat tidak hanya sebelum terjadinya perkawinan tetapi bisa juga dibuat setelah terjadinya perkawinan sepanjang dalam masa perkawinan dan implikasi hukumnya terhadap kewenangan notaris dalam pembuatan akta perjanjian kawin pasca Putusan Mahkamah Konstitusi Nomor 69/PUU-XIII/ 2015, karena putusan MK itu bersifat final dan mengikat, artinya semua pihak terutama notaris harus menghormati dan melaksanakan putusan MK Nomor 69/PUU-XIII/2015 tentang perjanjian kawin yang dibuat oleh para pihak boleh dibuat setelah terjadinya perkawinan dan harus disahkan oleh pejabat pencatat perkawinan yang berwenang atau notaris.
\end{abstract}

Kata Kunci: perjanjian kawin, kewenangan notaris, putusan MK No. 69/PUU-XIII/2015

Pada hakikatnya manusia diciptakan oleh Allah SWT untuk saling berpasang-pasangan satu dengan yang lain untuk membentuk suatu keluarga yang sakinah mawadah warahmah dan meneruskan garis keturunannya, yang diikat dalam ikatan suci perkawinan, seperti tercantum dalam Pasal 1 Undang-Undang Nomor 1 Tahun 1974 tentang Perkawinan.Perkawinan merupakan ikatan yang suci yang terjalin antara seorang lakilaki dan seorang perempuan yang didasarkan atas perasaan suka sama suka dan tidak ada paksaan serta didasari oleh suatu keyakinan dan kepercayaan yang mereka anut.Perkawinan tidak hanya sebagai sebagai suatu proses administrasi atau hanya hubungan keperdataan saja antara suami atau istri, melainkan juga menekankan pada 
adanya ikatan lahir bathin yang didasarkan atas Ketuhan Yang Maha Esa, dimana pasangan yang akan melangsungkan suatu pernikahan itu harus didasari ikatan satu dengan yang lain, serta tidak hanya karena dorongan alamiah untuk membuat keturunan sebagai penerus keluarga.

Pengakuan adanya ikatan lahir bathin antara suami dan istri ini menjadi tolok ukurperkawinan ini bukan karena paksaan dari orang lain. Perkawinan merupakan suatu perjanjian yang dilakukan oleh dua orang, tetapi berbeda dengan perjanjian pada umumnya karena perjanjian pada umumnya dibuat bebas oleh para pihak, sepanjang perjanjian tersebut tidak bertentangan dengan undang-undang yang berlaku, kesusilaan,dan ketertiban umum. Perkawinan disebut sebagai suatu bentuk perjanjian karena perkawinan sebelum terjadinya diawali dengan adanya persetujuan dari kedua belah pihak, baik dari calon mempelai maupun dari keluarga calon mempelai.

Perkawinan menimbulkan hak dan kewajiban pada pasangan suami-istri sesuai yang diatur dalam Undang-Undang Nomor1 Tahun 1974 tentang Perkawinan, bahwa suami dan istri harus saling mentaati dan menjalankan hak dan kewajibannya masing-masing secara seimbang. Akan tetapi,perkawinan juga dapat melahirkan persoalan tentang harta kekayaan yaitu mengenai harta benda bersama suami istri maupun harta pribadi dan atau harta bawaan (Butar-butar, 2012:22). Pengaturan tentang harta perkawinan tidak dimasukkan dalam ruang lingkup hukum harta kekayaan disebabkan karena anggapan bahwa perkawinan bukanlah salah satu cara untuk mendapatkan atau memperoleh harta/kekayaan. Meskipun diakui bahwa perkawinan berakibat kepada kedudukan seseorang terhadap kekayaan.Kekhawatiran yang lain adalah jika harta benda dalam perkawinan dimasukkan dalam lapangan hukum harta kekayaan yang dianut oleh sistem KUHPerdata, maka makna perkawinan sebagai sebagai suatu ikatan bathin antara seorang pria dengan seorang wanita sebagai suami istri dengan tujuan membentuk keluarga (rumah tangga) yang bahagia dan kekal berdasarkan Ketuhanan Yang Maha Esa akan bergeser menjadi suatu perikatan yang bertujuan mendapatkan harta kekayaan atau dianggap sebagai perikatan (Butarbutar, 2012:23).

Calon pasangan yangakan melangsungkan pernikahan biasanya tidak mempermasalahkan mengenai harta masing-masing atau percampuran harta yang akan terjadi setelah perkawinan karena didasari adanya rasa saling percaya dan memahami satu dengan yang lainnya. Tetapi dengan semakin berkembangnya jaman, situasi dan kondisi yang terjadi di masyarakat, dan karena adanya pengaruh dari budaya asing, mempengaruhi sedikit demi sedikit pola pikir dan pandangan di masyarakat. Harta bawaan atau harta masing-masing pihak sebelum terjadinya perkawinan menjadi salah satu fokus sorotan masalah sebelum pasangan melakukan pernikahan, hal ini dikarenakan semakin banyak pasangan perkawinan yang masing-masing bisa menghasilkan harta sendiri, sehingga kebutuhan untuk membuat perjanjian kawin mengenai pemisahan harta ini menjadi perlu diatur.

Undang-undang memperbolehkan kedua calon pasangan suami istri untuk membuat suatu perjanjian yang disebut "perjanjian perkawinan" atau "perjanjian kawin" dan umumnya hanya menyangkut seputar pengaturan terhadap harta perkawinan, yang dimaksudkan untuk mengantisipasi masalah-masalah yang mungkin timbul apabila perkawinan tersebut berakhir. Perjanjian perkawinan sebagai suatu perjanjian yang mengatur harta benda suami istri dimungkinkan untuk dibuat dan diadakan sepanjang tidak menyimpang dari asas atau pola yang ditetapkan oleh undang-undang (Soebekti, 2004:8-9). Hal ini dianggap perlu untuk mengantisipasi masalah yang timbul dalam rumah tangga. Kehidupan suatu keluarga atau rumah tangga selain masalah hak dan kewajiban sebagai suami istri, masalah harta benda juga merupakan salah satu faktor yang dapat menyebabkan timbulnya berbagai perselisihan atau ketegangan dalam suatu perkawinan, bahkan dapat menghilangkan kerukunan antara suami istri dalam kehidupan berumah tangga. Menghindari hal tersebut, maka dibuatlah perjanjian kawin antara pihak calon suami atau calon istri sebelum mereka melangsungkan perkawinan.

Perjanjian diartikan sebagai suatu hubungan hukum mengenai harta benda kekayaan antara dua pihak, dimana satu pihak berjanji atau dianggap berjanji untuk melakukan suatu hal atau untuk tidak melakukan sesuatu hal, sedangkan pihak lain berhak menuntut pelaksanaan janji itu. Perjanjian perkawinan tetap harus dibuat dengan mendasarkan pada syarat-syarat umum yang berlaku agar dapat menjadi syahnya suatu perjanjian sebagaimana diatur dalam pasal 1320 KUHPerdata. 
Isi yang diatur di dalam perjanjian kawin tergantung pada pihak calon suami atau calon istri, asalkan tidak bertentangan dengan undangundang, agama, dan kepatutan atau kesusilaan. Sedangkan bentuk dan isi perjanjian kawin dapat dibuat bebas sesuai kehendak pasangan calon pengantin sebagaimana diatur dalam undangundang. Definisi perjanjian kawin diatur dalam Pasal 29 UU No.1 tahun 1974, yaitu: (1) pada waktu atau sebelum perkawinan dilangsungkan, kedua pihak atas persetujuan bersama dapat mengadakan perjanjian tertulis yang disahkan oleh pegawai pencatat perkawinan, setelah mana isinya berlaku juga terhadap pihak ketiga sepanjang pihak ketiga tersangkut, (2) perjanjian tersebut tidak dapat disahkan bilamana melanggar batasbatas hukum, agama,dan kesusilaan, (3) perjanjian tersebut mulai berlaku sejak perkawinan dilangsungkan, (4) selama perkawinan berlangsung perjanjian tersebut tidak dirubah, kecuali bila kedua belah ada persetujuan untuk merubah dan perubahannya tidak merugikan pihak ketiga.

Berdasarkan KitabUndang-Undang Hukum Perdata (KUHPerdata) perubahan atas perjanjian perkawinan hanya mungkin dilakukan sebelum berlangsungnya perkawinan. Dalam hal terdapat perubahan maka perubahan tersebut harus dilakukan dengan cara dan bentuk yang sama seperti pembuatan perjanjian perkawinan tersebut. Perubahan tersebut juga hanya berlaku jika dihadiri dan disetujui oleh semua orang yang dulu telah menghadiri dan menyetujui perjanjian tersebut.

Para pihak calon mempelai perempuan dan calon mempelai laki-laki dapat membuat perjanjian perkawinan pada saat atau sebelum perkawinan dilangsungkan . Perjanjian biasbersifat notarial ataupun dibuat dibawah tangan dan akan berlaku sejak perkawinan dilangsungkan dan dilekatkan pada akta surat nikah dan merupakan satu bagian yang tidak terpisahkan dengan surat nikah. Suatu perjanjian perkawinan dapat dibuat dengan: (a) atas persetujuan atau kehendak bersama, (b) dibuat secara tertulis, (c) disahkan oleh pegawai pencatatan nikah, (d) tidak boleh bertentangan dengan hukum, agama dan kesusilaan (Prodjohamidjojo, 2002:30).

Perjanjian perkawinan tersebut tidak boleh bertentangan dengan ketertiban umum, kesusilaan, hukum dan agama. Tentang tidak boleh melanggar batas-batas hukum dalam hal ini diartikan secara luas yaitu tidak bertentangan dengan agama yang dianut oleh para pihak yang mengadakan perjanjian perkawinanitu pada saat membuat perjanjiannya dan pada saat perkawinan dilangsungkan.

Aturan mengenai perjanjian perkawinan berubah total setelah adanya putusan Mahkamah Konstitusi Nomor 69/PUU-XIII/2015 yang memperbolehkan pembuatan perjanjian kawin bisa dilakukan tidak hanya sebelum perkawinan seperti yang datur di dalam Undang-Undang Pokok Perkawinan Nomor1 Tahun 1974 tentang Perkawinan dan Pasal 147 Kitab Undang-Undang Hukum Perdata Tetapi bisa dibuat atau dilakukan perjanjian kawin setelah terjadinya perkawinan. Tetapi dengan syarat perjanjian kawin yang dibuat setelah terjadinya perkawinan harus dicatatkan dan dibuat oleh Notaris atau pejabat pencatat perkawinan yang berwenang.

Mengenai Putusan Mahkamah Konstitusi Nomor 69/PUU-XIII/2015 tentang di perbolehkannya suatu perjanjian kawin dibuat setelah terjadinya perkawinan atau selama terjadinya perkawinan di latar belakangi oleh permohonan pengajuan judicial review oleh Nyonya Ike Farida terhadap pengujian Pasal 21 ayat (1), ayat (3), dan Pasal 36 ayat (1); Pasal 29 ayat (1), ayat (3), ayat (4) dan Pasal 35 ayat (1) UU No.1 Tahun 1974 tentang Perkawinan terhadap UUD 1945. Nyonya Ike Farida seorang Warga Negara Indonesia (WNI) menikah dengan seorang warga Negara Jepang. Dalam perjalanan waktu perkawinan tersebut, nyonya Ike Farida ingin membeli aset berupa apartemen, tetapi karena pada saat mereka menikah dulu tidak membuat perjanjian kawin, pihak developer tidak bisa menjual unit apartemen tersebut karena adanya ketentuan sesuai Pasal 36 ayat (1) dan pasal 35 ayat (1) UU No 1 Tahun 1974 tentang Perkawinan, seorang perempuan WNI yang kawin dengan warga negara asing tidak bisa mempunyai hak milik untuk membeli tanah dan atau bangunan tanpa adanya perjanjian kawin terlebih dahulu.

Oleh karenanya pihak developer memutuskan untuk tidak melakukan Perjanjian Pengikatan Jual Beli (PPJB) ataupun membuat Akta Jual Beli (AJB) dengan pemohon Nyonya Ike Farida, karena dianggap akan melanggar Pasal 36 ayat (1)dan pasal 35 ayat (1) UU No 1 Tahun 1974 tentang Perkawinan. Merasa dibedakan haknya sebagai warga Negara Indonesia, kemudian Nyonya Farida mengajukan judicial review mengenai permasalahan tersebut. Dalam Amar putusannya Mahkamah Konstitusi mengeluarkan putusan No. 69 /PUU-XIII/2015 yang menerima sebagaian 
permohonan judicial review dari pemohon Nyonya Ike Farida yaitu dalam Pasal 29 ayat (1), Pasal 29 ayat (3), Pasal 29 ayat (4)Undang-Undang No.1 Tahun 1974 tentang Perkawinan.

Pasal 29 ayat (1) Undang-UndangNomor 1 Tahun 1974 tentang Perkawinan di ubah oleh Mahkamah Konstitusi menjadi: Pada waktu, sebelum dilangsungkan atau selama dalam ikatan perkawinan, kedua belah pihak atas persetujuan bersama dapat mengajukan perjanjian tertulis yang disahkan oleh pegawai pencatat perkawinan atau notaris, setelah mana isinya berlaku juga terhadap pihak ketiga sepanjang pihak ketiga tersangkut. Pasal 29 ayat (3) Undang-UndangNomor 1 Tahun 1974 tentang Perkawinan diubah oleh Mahkamah Konstitusi menjadi: Perjanjian tersebut mulai berlaku sejak perkawinan dilangsungkan, kecuali ditentukan lain dalam perjanjian perkawinan.Pasal 29 ayat (4) Undang-UndangNomor 1 Tahun 1974 tentang Perkawinan diubah oleh Mahkamah Konstitusi menjadi: Selama Perkawinan berlangsung, perjanjian perkawinan dapat mengenai harta perkawinan atau perjanjian lainnya ,tidak dapat dirubah atau dicabut kecuali bila dari kedua belah pihak ada persetujuan untuk mengubah atau mencabut dan perubahan atau pencabutan itu tidak merugikan pihak ketiga.

Apabila terjadi sengketa akibat dari perubahan isi perjanjian kawin yang dibuat setelah adanya putusan Mahkamah Konstitusi (MK) ini bisa di selesaikan sengketa ini dengan cara Litigasi dan Non Litigasi. Tetapi bisa juga sengketa di selesaikan dengan cara Alternative Dispute Resolution (ADR) (Safa'at, 2016:81-82), yaitu penyelesaian sengketa yang diselesaikan di luar pengadilan seperti negoisasi, mediasi dan konsiliasi.

Oleh karena itu agar perjanjian kawin ini bisa mengikat para pihak dan bisa menjadi pegangan pihak ketiga, maka harus di daftarkan dan di sahkan oleh pegawai pencatat perkawinan atau di Kantor Catatan Sipil setempat, agar ada keabsahandari pejabat yang berwenangyang akan berdampak pada keberlakuan dari isi perjanjian itu sendiri bagi para pihak maupun pihak ketiga yang terkait dengan perjanjian tersebut. Perjanjian kawin awalnya bertentangan dengan nilai yang ada dalam masyarakat Indonesia, sebagai bangsa timur perjanjian kawin dianggap sebagai hal yang tabu, maraknya kasus perceraian yang disebabkan oleh faktor ekonomi dapat dijadikan salah satu alasan calon pasangan suami istri membuat perjanjian kawin. Walaupun setiap pasangan yang akan menikah tidak mengharapkan adanya perceraian, tetapi hanya mengantisipasi apabila terjadi hal-hal yang tidak di inginkan terjadi di kemudian hari.

\section{METODE}

Penulisan artikel ilmiah ini menggunakan metode yuridis empiris, dengan pendekatan yang bersifat yuridissosiologis, dimana pendekatan ini mengkaji kaidah-kaidah hukum yang ada di dalam Putusan Mahkamah Konstitusi (MK) No. 69XIII/2015, perundang-undangan, pendekatan konseptual dan wawancara. Penulisan artikel ilmiah ini didasarkan pada pertimbangan antara lain:

1. Sampai saat ini masih banyak kantor Notaris yang belum mau menerima pekerjaan membuat Akta Perjanjian Kawin setelah adanya Putusan MK nomor 69/PUU-XIII/2015 dimana perjanjian kawin bisa dibuat sebelum, saat dan setelah terjadinya perkawinan.

2. Karena Hakim Mahkamah Konstitusi mengeluarkan putusan MK Nomor 69/PUUXIII/2015 yang kontradiktif dengan UndangUndang No. 1 Tahun 1974 tentang perkawinan dimana di dalam peraturan sebelumnya perjanjian kawin hanya bisa dibuat sebelum perkawinan.

Jenis dan bahan hukum yang digunakan dalam penulisan kajian ini adalah meliputi data primer dan data sekuender. Data primer dalam kajian ini meliputi data yang berupa pengalaman, pendapat, pernyataan yang diperoleh dari keterangan narasumber atau responden yang berkaitan dengan Putusan Mahkamah Konstitusi (MK) No. 69/PUU-XIII/2015 dalam hal putusan tentang perjanjian kawin yang bisa dibuat setelah terjadinya perkawinan dan harus di sahkan oleh pegawai pencatat perkawinan atau Notaris. Data primer dalam artikel ilmiah ini diperoleh dari hasil wawancara mendalam dan observasi di beberapa kantor notaris di wilayah JakartaTimur dan di Kantor Hakim Mahkamah Konstitusi, di kantor Pengadilan Agama Jakarta Timur, Kantor Pengadilan Negeri Jakarta Timur.Data sekunder dalam artikel ilmiah ini didapatkan dari:

a. Undang- Undang Dasar Negara Republik Indonesia Tahun 1945

b. Kitab Undang- Undang Hukum Perdata (KUHPerdata)

c. Undang- Undang No. 1 Tahun 1974 tentang Perkawinan (Lembaran Negara Republik Indonesia Tahun 1974 Nomor 1) 
d. Undang-Undang Republik Indonesia Nomor 2 Tahun 2014 tentang perubahan atas UndangUndang Nomor 30 Tahun 2004 tentang Jabatan Notaris , Lembaran Negara Republik Indonesia Tahun 2014 Nomor 3.

e. Putusan Mahkamah Konstitusi (MK) Nomor. 69/PUU-XIII/2015 tentang pembuatan perjanjian kawin yang bisa dibuat setelah perkawinan.

Teknik analisa data yang dipergunakan dalam penulisan jurnal ini adalah deskriptif kualitatif, dimana mendeskripsikan dan menganalisa datadata yang di peroleh dilapangan dan kemudian dikaitkan dengan teori-teori hukum berupa Teori Keputusan, Teori Kewenangan, dan Teori Tanggung Jawab Hukum, serta peraturan perundang-undangan yang berkaitan antara lain: UUD NRI 1945, KUHP, UU No.1 Tahun 1974, UUJN No.2 Tahun 2014, Putusan MK No. 69/ PUU-XIII/2015. Agar dapat mengambil suatu kesimpulan dan saran dengan metode berpikir yang induktif dari persoalan yang khusus ke persoalan yang umum, sehingga menghasilkan gambaran yang sesuai dengan keadaan yang sebenarnya.

\section{HASIL DAN PEMBAHASAN}

\section{Dasar Rasio Legis Putusan Mahkamah Konstitusi (MK) Nomor 69/PUU-XIII/2015}

Pasal 24 ayat (2) UUD 1945 menyebutkan bahwa kekuasaan kehakiman di Indonesia dilakukan oleh sebuah lembaga yang disebut Mahkamah Agung (MA) dan badan peradilan yang berada dibawahnya seperti peradilan umum, peradilan agama, peradilan militer, peradilan tata usaha Negara, dan oleh sebuah lembaga Mahkamah Konstitusi (MK). Perbedaan antara peradilan di Mahkamah Konstitusi dengan peradilan lainnya adalah, Peradilan di Mahkamah konstitusi adalah peradilan yang bersifat Normatif yang hanya mengadili norma yang ada di dalam ketentuan UUD 1945, sedangkan dalam peradilan lain selain peradilan MK, disebut sebagai peradilan yang riil.

Berdasarkan Pasal 24C Ayat (1) UUD 1945 yang ditegaskan kembali dalam Pasal 10 ayat (1) huruf a sampai dengan huruf d UU No.24 Tahun 2003, kewenangan Mahkamah Konstitusi (MK) adalah menguji undang-undang terhadap UUD 1945, memutus sengketa kewenangan lembaga Negara yang kewenanganya diberikan oleh UUD
1945, memutus pembubaran partai politik, memutus perselisihan tentang hasil pemilihan umum (pemilu). Tambahan kewenangan Mahkamah Konstitusi (MK) adalah memberikan keputuan atas pendapat DPR bahwa Presiden dan/atau Wakil Presiden telah melakukan pelanggaran hukum, atau perbuatan tercela atau tidak memenuhi syarat sebagai Presiden dan/atau Wakil Presiden sebagaimana dimaksud dalam UUD 1945. Berdasarkan latar belakang tersebut kemudian Ibu Ike Farida seorang warga Negara Indonesia yang menikah dengan seorang warga warga Negara Jepang yang pada saat akan membeli property berupa rumah susun tidak bisa karena alasan pada saat dulu menikah dengan suaminya yang warga Negara asing tidak membuat sebuah perjanjian kawin. Adapun permohonan pengujian undang-undang (norma) terhadap UUD 1945 yang dimohonkan oleh Ibu Ike Farida adalah sebagai berikut :

A. Norma Undang-Undang Nomor 5 Tahun 1960

1. Pasal 21 ayat (1). Hanya warga negara Indonesia dapat mempunyai hak milik

2. Pasal 21 ayat (3). Orang asing yang sesudah berlakunya undang-undang ini memperoleh hak milik karena pewarisan tanpa wasiat atau percampuran harta karena perkawinan, demikian pula warga negara Indonesia yang mempunyai hak milik dan setelah berlakunya undang-undang ini kehilangan kewarganegaraannya wajib melepaskan hak itu di dalam jangka waktu satu tahun sejak diperolehnya hak tersebut atau hilangnya kewarganegaraan itu. Jika sesudah jangka waktu tersebut lampau hak milik itu dilepaskan maka hak tersebut hapus karena hukum dan tanahnya jatuh pada negara, dengan ketentuan bahwa hak-hak pihak lain yang membebaninya tetap berlangsung.

3. Pasal 36 ayat (1). Pihak yang dapat mempunyai hak guna banguna ialah: a) warga negara Indonesia, b) Badan hukum yang didirikan menurut hukum Indonesia dan berkedudukan di Indonesia.

B. Norma Undang-Undang No 1 Tahun 1974

1. Pasal 29 ayat (1). Pada waktu atau sebekum perkawinan dilangsungkan, kedua belah pihak atas persetujuan bersama dapat megadakan perjanjian tertulis yang disahkan oleh pegawai pencatat perkawinan, stelah 
mana isinya berlaku terhadap pihak ketiga sepanjang pihak ketiga tersangkut.

2. Pasal 35 ayat (1). Harta Benda yang diperoleh selama perkawinan menjadi harta bersama.

C. Norma Undang-Undang Dasar 1945

1. Pasal 27 ayat (1) UUD 1945. Segala warga negara bersamaan kedudukannya di dalam hukum dan pemerintahan dan wajib menjunjung hukum dan pemerintahan itu dengan tidak ada kecualinya.

2. Pasal 28D ayat (1) UUD 1945. Setiap orang berhak atas pengakuan, jaminan, perlindungan, dan kepastian hukum yang adil serta perlakuan yang sama dihadapan hukum.

3. Pasal 28E ayat (1) UUD 1945. Setiap orang berhak memeluk agama dan beribadat menurut agamanya,memilih pendidikan dan pengajaran, memilih pekerjaan, memilih kewarganegaraan, memilih tempat tinggal di wilayah Negara dan meninggalkannya serta berhak kembali.

4. Pasal 28H ayat (1) UUD 1945. Setiap orang berhak hidup sejahtera lahir dan bathin, bertempat tinggal, dan mendapatkan lingkungan hidup yang baik dan sehat serta berhak memperoleh pelayanan kesehatan.

5. Pasal 28H ayat (4) UUD 1945. Setiap orang berhak mempunyai hak milik pribadi dan hak milik tersebut tidak boleh diambil alih secara sewenang-wenang oleh siapapun.

6. Pasal 28I ayat (2) UUD 1945. Setiap orang bebas dari perlakuan yang bersifat diskriminatif atas dasar apapun dan berhak mendapatkan perlindungan terhadap perlakuan yang bersifat diskriminatif itu.

Atas dasar permohonan pengujian pasalpasal dalam undang-undang tersebut terhadap UUD 1945 yang diajukan oleh Ibu Ike Farida sehingga Mahkamah Konstitusi mengeluarkan Putusan Nomor 69/PUU-XIII/2015.

Implikasi Hukum Terhadap Kewenangan Notaris Dalam Membuat Akta Perjanjian Kawin Pasca Putusan MK Nomor 69/PUUXIII/2015

Dasar Kewenangan Notaris dalam menjalankan tugas dan jabatanya sebagai notaris untuk membuat akta otentik dalam hal ini akta perjanjian perkawinan diatur di dalam Undang-
Undang Republik Indonesia Nomor 2 Tahun 2014 Tentang Perubahan Atas Undang-Undang Nomor 30 Tahun 2004 Tentang Jabatan Notaris Pasal 15. Penjelasan dalam Pasal ini memberikan gambaran yang jelas mengenai wewenang seorang notaris dalam menjalankan tugas membuat akta otentik bagi para pihak. Baik itu akta perjanjian perkawinan atau akta-akta otentik yang lainnya. Pasca putusan Mahkamah Konstitusi No. 69/ PUU-XIII/2015 tentang dasar pembuatan perjanjian perkawinan yang bisa dibuat sebelum, pada saat dan setelah terjadinya perkawinan banyak menjadi kajian notaries.

Ibu Neily Irawati Iswari, S.H.,M.Si, M.Kn. Notaris di Wilayah Kota Administrasi Jakarta Timurmenyatakan bahwa sebagian besar notarisnotaris di wilayah Kota Administrasi Jakarta Timur belum ada yang membuat akta perjanjian perkawinan dengan berbagai alas an. Salah satu alasan dari Ibu Notaris Neily adalah belum adanya peraturan yang jelas dan tegas mengenai aturan pelaksanaanya untuk para notaris. Hal ini berdasarkan pada prinsip kehati-hatian yang lebih dari para notaris sebagai upaya melindungi diri dari hal-hal yang akan terjadinya di kemudian hari atas itikad yang tidak baik dari para pihak. Pihak yang tidak bertanggung jawabdapat melakukan tindakan penyelundupan hukum dan kemungkinan menimbulkan kerugian bagi pihak ketiga yang tersangkut dengan adanya putusan Mahkamah Konstitusi (MK) ini yang memperbolehkan pembuatan perjanjian perkawinan ini dibuat sebelum, pada saat dan setelah terjadinya perkawinan. Ibu Dr.Yurisa Martanti, S.H,M.H, Notaris di wilayah Kota Administrasi Jakarta Timur dan sekaligus sebagai Ketua Bidang Pendidikan dan Pelatihan (Diklat) Ikatan Notaris Indonesia (INI) pusat menyatakan bahwa: INI sebagai Induk organisasi notaris seluruh Indonesia menyatakan sikap bahwa INI menghargai Putusan Mahkamah Konstitusi No. 69/PUU-XIII/2015 ini, karena putusan ini merupakan yurisprudensi yang merupakan salah satu sumber hukum. Yurisprudensi merupakan putusan yang telah berkekuatan hukum tetap (inkracht van gewijsde) dan keputusan Mahkamah Konstitusi (MK) bersifat final dan mengikat. Pelaksanaan dilapanganpembuatan akta perjanjian perkawinan, notaris boleh memakai ketentuan yang ada di dalam Kitab Undang-Undang Hukum Perdata (KUHPerdata) atau mengikuti ketentuan yang ada dalam Putusan Mahkamah Konstitusi (MK) 
No. 69/PUU-XIII/2015 tentang perubahan Pasal 29 Undang-Undang No. 1 Tahun 1974 yang memperbolehkan perjanjian perkawinan dibuat sebelum, pada saat dan setelah terjadinya perkawinan sepanjang masih dalam masa perkawinan.

Penulis mendapatkan gambaran mengenai implikasi hukum Putusan Mahkamah Konstitusi (MK) No.69/PUU-XIII/2015 adalah bahwa karena Putusan Mahkamah Konstitusi (MK) ini bersifat final dan mengikat, sehingga tidak ada upaya hukum lagi yang bisa ditempuh maka putusan tersebut harus bisa dijakankan. Notaris dan para pihak diberikan kebebasan pilihan dalam membuat perjanjian kawin, apakah akan tunduk dengan aturan yang ada dalam Putusan MK No. 69/PUU-XIII/2015 mengenai perjanjian perkawinan bisa dibuat sebelum, pada saat dan setelah terjadinya perkawinan sepanjang masih dalam masa perkawinan sepanjang tidak merugikan bagi kepentingan pihak ketiga, atau notaris dan para pihak akan tunduk pada peraturan yang ada di dalam ketentuan Undang-Undang No. 1 Tahun 1974 tentang Perkawinan dan ketentuan yang ada di dalam Kitab Undang-Undang Hukum Perdata yang menyatakan bahwa perjanjian

\section{DAFTAR RUJUKAN}

\author{
Butar-Butar,Elisabeth Nurhaini, Hukum Harta \\ Kekayaan Menurut Sistimatika KUH \\ Perdata dan Perkembangannya, \\ Bandung,Refika Aditama, 2012. \\ Prodjohamidjojo, Martiman. 2007.Hukum
} Perkawinan Indonesia. Jakarta: Legal Center Publishing.

Safa'at, Rachmad. 2016. Advokasi dan Alternatif Penyelesaian Sengketa Edisi Revisi. Malang: Surya Pena Gemilang. perkawinan hanya bisa dibuat sebelum terjadinya perkawinan.

\section{SIMPULAN}

Dasar Rasio Legis Putusan Mahkamah Konstitusi (MK ) No. 69/PUU-XIII/2015 adalah bahwa maksud pembentukan Mahkamah Konstitusi di Indonesia yang paling pokok adalah untuk menjaga agar tidak ada Undang-Undang yang bertentangan dengan Undang-Undang Dasar (UUD) 1945 , setiap warga negara Indonesia berhak menuntut hak-hak dasarnya sesuai yang ada dalam amanat Undang-Undang Dasar 1945.

Implikasi hukum Putusan Mahkamah Konstitusi (MK) No. 69/PUU-XIII/2015 terhadap kewenangan notaris dalan membuat akta perjanjian kawin adalah: Putusan Mahkamah Konstitusi No. 69/PUU-XIII/2015 ini merupakan yurisprudensi yang merupakan salah satu sumber hukum. Yurisprudensi merupakan putusan yang telah berkekuatan hukum tetap (inkracht van gewijsde) dan keputusan Mahkamah Konstitusi (MK) bersifat final dan mengikat, sehingga harus tetap dilaksanakan oleh semua pihak baik notaris, dan para pihak.

\section{Kitab Undang-Undang Hukum Perdata.}

Republik Indonesia. 1974. Undang-Undang No I tahun 1974 tentang Perkawinan.

Republik Indonesia. 2014. Undang-Undang No 2 Tahun 2014 tentang Jabatan Notaris.

Republik Indonesia. 2003. Undang-Undang No 24 Tahun 2003 tentang Mahkamah Konstitusi. 